\title{
Stem Cells in the Human Breast
}

\author{
Ole William Petersen ${ }^{1}$ and Kornelia Polyak ${ }^{2}$ \\ ${ }^{1}$ Department of Cellular and Molecular Medicine, Faculty of Health Sciences, The Panum Building, University \\ of Copenhagen, DK-2200 Copenhagen N, Denmark \\ ${ }^{2}$ Department of Medical Oncology, Dana-Farber Cancer Institute, Department of Medicine, Brigham and \\ Women's Hospital, and Department of Medicine, Harvard Medical School, Boston, Massachusetts 02115 \\ Correspondence: o.w.petersen@sund.ku.dk
}

\begin{abstract}
The origins of the epithelial cells participating in the development, tissue homeostasis, and cancer of the human breast are poorly understood. However, emerging evidence suggests a role for adult tissue-specific stem cells in these processes. In a hierarchical manner, these generate the two main mammary cell lineages, producing an increasing number of cells with distinct properties. Understanding the biological characteristics of human breast stem cells and their progeny is crucial in attempts to compare the features of normal stem cells and cancer precursor cells and distinguish these from nonprecursor cells and cells from the bulk of a tumor. A historical overview of research on human breast stem cells in primary tissue and in culture reveals the progress that has been made in this area, whereas a focus on the cell-of-origin and reprogramming that occurs during neoplastic conversion provides insight into the enigmatic way in which human breast cancers are skewed toward the luminal epithelial lineage.
\end{abstract}

W hat defines a mammary epithelial stem cell has been a source of much contention. The different profiles put forward have relied on different experimental systems, based on human and rodent models, in vivo and in culture. However, recently the field has moved forward dramatically owing to the introduction of new fluorescence-activated cell sorting (FACS) methods, culture conditions that allow singlecell cloning, and techniques for nonadherent expansion of cells as embryoid-body-ike spheres and tissue-specific differentiation of cells in three-dimensional extracellular matrices (Stingl et al. 2001; Gudjonsson et al. 2002; Dontu et al. 2003). Most importantly, genetically engineered, immuno-suppressed mouse strains are now available for xenografting and physiological growth and differentiation of normal human breast epithelial cells either in the cleared fat pad or under the renal capsule (Dontu and Wicha 2005; Eirew et al. 2008; Lim et al. 2009). Collectively, these different approaches have led to the isolation of cells defined by a combination of different cell-surface markers (CD44, CD29, CD49f, EpCAM, and CD24) that seem to be enriched for a cell type that can repopulate the mammary gland in vivo. Further profiling of this cell type with reference to the two main lineages in the human breast-luminal epithelial cells and basal/myoepithelial cells_-strongly

Editors: Mina Bissell, Kornelia Polyak, and Jeffrey Rosen

Additional Perspectives on The Mammary Gland as an Experimental Model available at www.cshperspectives.org

Copyright (C) 2010 Cold Spring Harbor Laboratory Press; all rights reserved; doi: 10.1101/cshperspect.a003160

Cite this article as Cold Spring Harb Perspect Biol 2010;2:a003160 
points toward a basal-cell-like source of human breast stem cells (Shipitsin et al. 2007).

With these new tools in hand, we are set to accomplish in the human breast what has already been accomplished in the hematopoietic system and leukemia, that is to comprehensively define a lineage hierarchy with a view to finding the cellular origin of breast cancer and, thus, an explanation for the tumor heterogeneity observed. Eventually, this should lead to the discovery of novel drug targets for cancer treatment. Here, we review what is known about human breast epithelial stem cells and their progeny. We focus on plasticity and differentiation within the luminal epithelial lineage, because most breast cancers display characteristics of this lineage.

\section{HUMAN BREAST DEVELOPMENT}

Classification of somatic cells or cancer in general is often based on knowledge of the immature version of a given cell type or lineage as it develops in the fetus. The human breast is derived from a flask-shaped epithelial structure in the ectoderm referred to as the mammary primordium that appears at week 14 of gestation (the primary bud stage) (Fig. 1). At this point, two cell types can be identified: central and peripheral (or basal) primary bud cells. At the epidermal junction these two cell types meet with the upper and basal epithelial cell layers of the epidermis, respectively. The mammary primordium can be distinguished from the surrounding primitive skin by a striking reduction in staining for keratin K14 in the basal layer of epithelial cells at the neck of the primary bud (Fig. 1). In the following weeks, solid cords of epithelial cells, known as secondary epithelial outgrowths or mammary projections, migrate into the mesenchyme from the growing primary bud (Jolicoeur 2005). These are composed of central and basal cells that stain for both keratin K14 and K19, except at the very tip, which lacks keratin K19. Central slitlike spaces form the nascent lumens of the future ducts. At near term, the secondary outgrowths have branched and become fully canalized. At this point, the breast consists of ducts that terminate in rounded buds or lobule-like structures (Fig. 1). The segregation of cells into keratin K19-positive luminal epithelial and a keratin K14-positive basal/ myoepithelial lineages is already evident at this time (Howard and Gusterson 2000). Development of the human breast differs from that of mice in two respects: the lack of a regular fad pad and the presence of a third cell type from the luminal epithelial lineage that express basal markers in addition to the luminal markers (double positive cells) (Fig. 1).

Until puberty, the breast remains relatively immature. It consists of ducts that branch one or several times and end in terminal buds or variably developed terminal ductal-lobular units (TDLUs) (Fig. 2). In terms of lineages, there is little or no difference between the fetal and infant breast. However, after puberty a fourth cell type emerges within the luminal epithelial lineage; this is keratin K19 and K14 double negative (Fig. 2). These cells are nevertheless luminal epithelial, because they express other markers of this lineage, such as mucin and simple keratins K8/18. That they indeed behave as a unique branch within the luminal epithelial lineage is evident from staining of the fully mature lactating breast. Here entire lobules appear to have expanded clonally from either keratin K19-positive or K19-negative precursor cells (Fig. 2). When fully developed by the age of 18 , the human breast is composed of large, segmental, and subsegmental ducts, and terminal ductal-lobular units of varying sizes, and four cell types are distinguishable by expression of keratins K19 and K14 (Fig. 2).

Following pregnancy and lactation, the human breast ducts involute to an extent almost indistinguishable from that of the prepregnancy breast except for the presence of slightly larger lobules (Russo and Russo 2004). The fact that endbuds are quite infrequent in the normal adult human breast is puzzling in light of the fact that in mice the number of endbuds correlates directly with susceptibility to cancer (Hilakivi-Clarke and de Assis 2006). Clearly, the human female breast is highly susceptible to breast cancer. One explanation for this inconsistency could be the lack of comparable chronology between mouse and human 

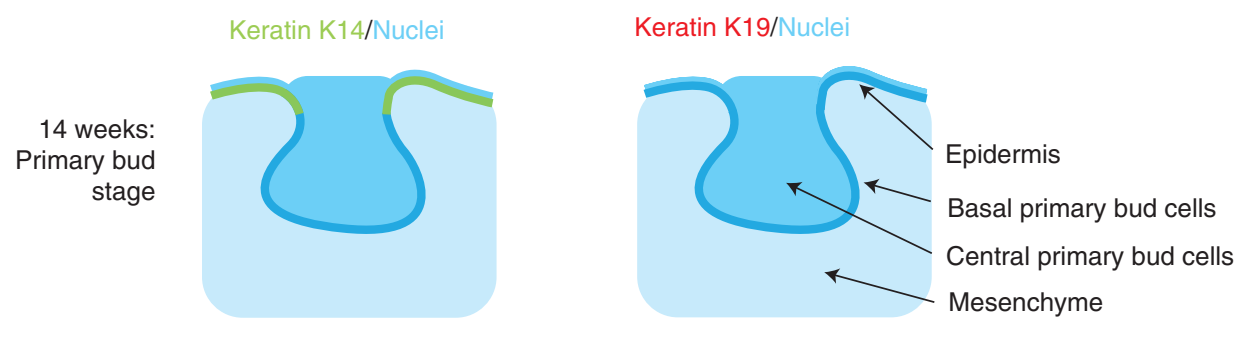

\section{1 weeks: Secondary bud stage}
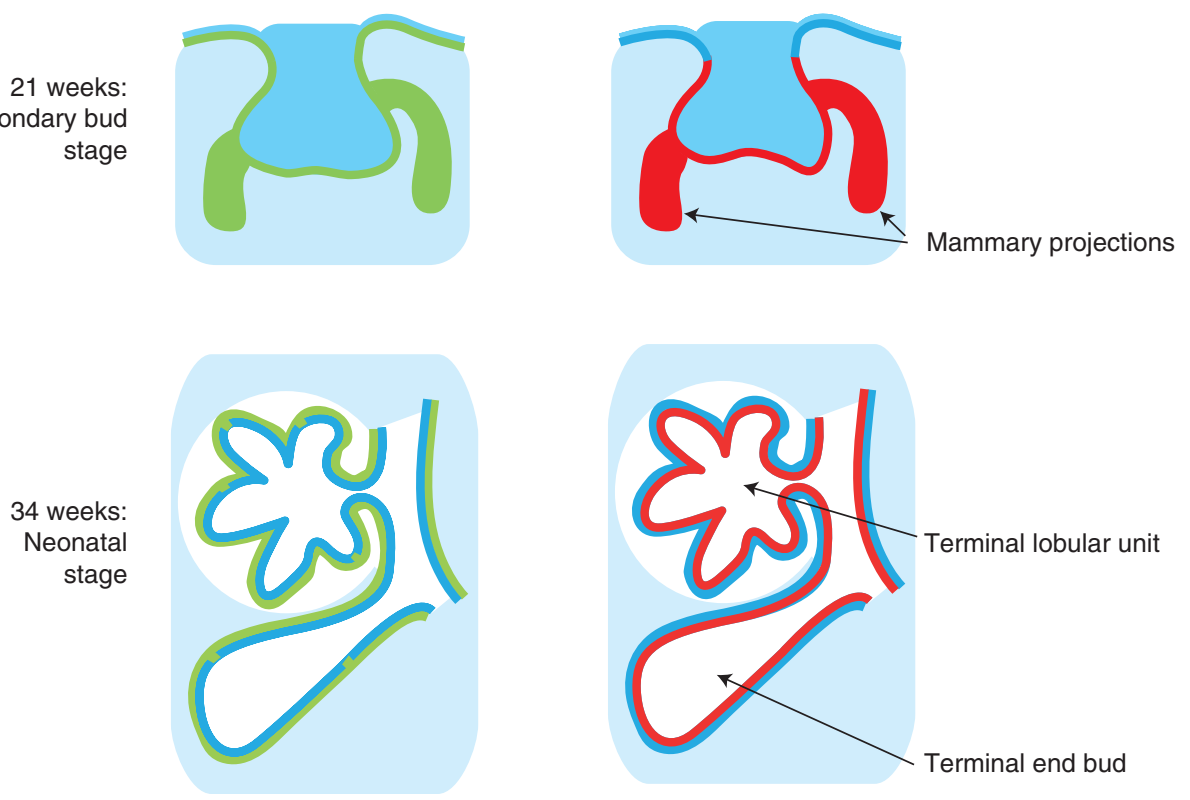

Figure 1. Fetal human breast. Schematic representation of a fetal human breast at the primary bud stage (upper row), the secondary bud stage (middle row), and the neonatal stage (lower row). Nuclei, keratin K14 and keratin K19 are represented by blue, green, and red, respectively. At the primary bud stage, the human breast primordium consists of an inner layer of central primary bud cells and an outer layer of basal primary bud cells surrounded by mesenchyme. Significantly, the basal primary bud cells differ from the basal epidermal cells by the lack of keratin K14. At the secondary bud stage mammary projections are characterized by the dual expression of keratins K14 and K19. At the neonatal stage the luminal and basal epithelial lineages are clearly separated. Double-positive cells for keratin K14 and K19 are scattered in terminal lobular units and end buds.

mammary development. This becomes clear if we examine the few studies of human fetuses. In mice, end buds appear most frequently in the period between the development of the epithelial rudiment at birth and ductal elongation as completed at puberty. Therefore, if cancer susceptibility relates to the number of endbuds, the critical period is postnatal in mice, whereas in humans it is fetal. This would explain a number of observations in humans implicating the intrauterine hormonal and nutritional milieu as independent correlates of breast cancer risk in adulthood (Hilakivi-Clarke and de Assis 2006). With this in mind, and taking into consideration that at different times different stem cells may orchestrate tissue development, homeostasis, and repair, we can speculate that, in the breast, different stem cells drive fetal and adult mammary gland development and homeostasis. This may explain why cancer precursor cells might be distinct from the original mammary stem cells, as was recently 
O.W. Petersen and K. Polyak
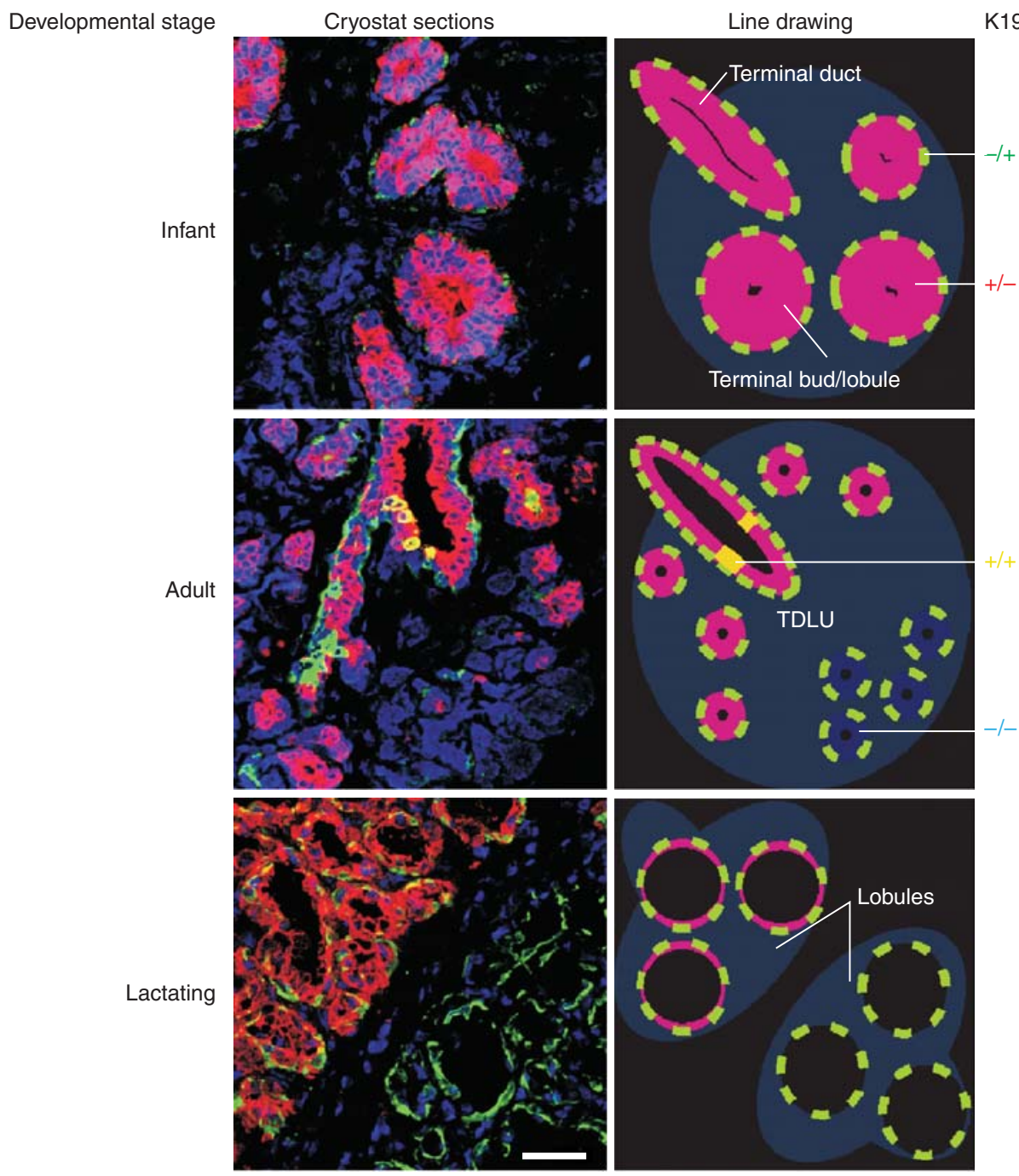

Figure 2. Postnatal human breast. Multicolor imaging (left column) and schematic representation (right column) of cryostat sections of the human breast at the infant (upper row), adult (middle row), and lactating (lower row) stage stained against nuclei (blue), keratin K14 (green), and keratin K19 (red). Whereas the infant breast consists of up to three cell types in terms of keratin K14 and K19 expression $(-/+$; +/ - , and rare $+/+)$ the adult breast shows a fourth cell type being double-negative $(-/-)$. These cells are luminal and may expand clonally and differentiate during lactation side by side with $+/$ - lobules (Scale bar $=50 \mu \mathrm{m})$.

proposed for basal-like breast cancer (Lim et al. 2009).

\section{PRIMARY TISSUE CULTURE STUDIES}

The existence of mammary epithelial stem cells has been hypothesized for as long as the enormous regenerative capacity of the breast in vivo has been appreciated (for review see Bissell and Inman 2008). The first evidence for the existence of these cells, however, was the demonstration that normal human breast epithelial cells can grow in tissue culture. This was achieved originally by the use of enzymatic disaggregation, feeder cells and medium conditioned by different established cell lines (Stampfer et al. 1980). Before using these conditions, researchers could not get breast epithelial cells 
to adhere well to tissue culture plastic, and traditional serum supplementation facilitated overgrowth by fibroblasts. The Stampfer and Hallowes' breakthrough allowed a more systematic search for optimal culture conditions for human breast epithelial cells. In 1984 Martha Stampfer succeeded in finding a combination of a gentle disaggregation protocol and a serumfree medium supplemented with bovine pituitary extract, which supported serial subculture for up to 20 passages with a 1:10 split ratio, and after a crisis, rapid clonal growth with plating efficiencies up to $35 \%$ (Hammond et al. 1984). The cell type that eventually emerged from these efforts was neither a differentiated myoepithelial cell nor a bona fide luminal epithelial cell. Rather it was a relatively undifferentiated basal-like cell, and, therefore, it was proposed that this postcrisis cell might represent human breast epithelial stem cells (Hammond et al. 1984).

A similar conclusion was reached in an independent study based on a completely different approach. Here, long-term growth of human breast epithelial cells was achieved for more than 50 generations (corresponding to a 1000fold expansion of the original inoculum), based on a combination of serum supplementation and low $\mathrm{Ca}^{2+}$ to overcome renewal inhibition (Soule and McGrath 1986). Intriguingly, under these conditions, clonal cells were released from the culture surface as free-floating cells in suspension, which could then be replated for further expansion. The cells were characterized as breast epithelial cells because, under differentiating conditions (high $\mathrm{Ca}^{2+}$ concentration), they formed domes in monolayer culture, a functional hallmark of luminal epithelial cells, and ductlike structures inside collagen gels (Soule and McGrath 1986).

\section{CYTOKERATIN STAINING PATTERNS IN NORMAL AND NEOPLASTIC BREAST TISSUES}

Another breakthrough in the search for human breast stem cells came with the ability to raise antibodies against any of the 20 different keratin types expressed in different combinations in human organs and tissues. A landmark paper in 1985 reported the first reliable staining of the basal/myoepithelial lineage within the human breast (Dairkee et al. 1985). Surprisingly, a fraction of cancer cells also stained with the keratin 14 antibody in a subset of breast carcinomas, but the majority displayed a luminal staining pattern. This mixed phenotype provided the first evidence for multilineage evolution within the tumor (Dairkee et al. 1985). Based on genome-wide gene expression profiling of breast tumors, we now know that these carcinomas belong to the basal-like subtype of breast cancers, which are assumed to be stem cell-derived or to have acquired properties of stem cells during transformation (Sørlie et al. 2001). Similar data were generated in studies using an antibody against keratin 5 (K5), a partner of keratin 14 in keratin filaments (Nagle et al. 1986). Myoepithelial/basal cells of the normal breast stained with antikeratin 5 in a manner similar to anti-K14. However, a subset of luminal cells in the terminal ducts also stained positive for $\mathrm{K} 5$ - these cells were presumed to give rise to the minority of $\mathrm{K} 5$-positive breast carcinomas potentially representing human breast epithelial stem cells (Nagle et al. 1986). More elaborate studies employing multicolor imaging showed that these cells (terminal ductal cells) may represent early progenitors and are candidates for precursor cells of basal-like breast cancer (Bocker et al. 2002; Gudjonsson et al. 2002; Ginestier et al. 2007; Villadsen et al. 2007; Lim et al. 2009; Pece et al. 2010).

An important early study using the new monoclonal antibodies against keratins visualized the staining pattern of antibody BA17 against keratin K19 (Bartek et al. 1985). It found that more than $95 \%$ of primary human breast carcinomas and all metastatic lesions were homogeneously positive for this keratin. This was a remarkable observation in light of the heterogeneity of human breast carcinomas and supported the idea that breast cancer originates from normal keratin K19 positive luminal epithelial cells. Even more surprising was the high degree of heterogeneity of keratin K19 expression in the normal breast and benign breast lesions in contrast to its nearly uniform 
expression in tumors. The results supported a model in which there is a lineage hierarchy of stem cells and their progeny in the normal breast, and this differentiation repertoire is lost in breast cancer (Bartek et al. 1985). The phenomenon was also observed in cultured cells (Rudland et al. 1985). In the normal breast a subset of luminal epithelial cells were found to be keratin K19-negative and the fraction of these negative cells increased under proliferative conditions such in benign epithelial hyperplasia. Keratin K19-negative luminal cells were therefore proposed to be proliferative precursors of more quiescent keratin K19-positive cells. Thus, a subset of keratin K19-negative luminal epithelial cells might represent human breast epithelial stem cells (Bartek et al. 1985).

Given the current view that human mammary epithelial stem cells are most likely to be located in the basal layer, the increase in keratin K19-negative luminal cells in benign hyperproliferative conditions indicates that these cells might be early descendants of adult breast epithelial stem cells and that the expansion of this compartment in benign disease is merely the consequence of the potential expansion of a true premalignant compartment. Indeed, premalignant lesions located next to benign hyperproliferative lesions were found to be K19-positive-lineage restricted (Bartek et al. 1985). If this hypothesis is correct, it could explain why all established breast epithelial cell lines from long-term, primary-cell-derived cultures of reduction mammoplasties are completely keratin K19-negative but show some luminal features even following cellular transformation. If so, keratin K19-positive cells presumably do not originate from postnatal human breast epithelial stem cells. An alternative source of keratin K19-positive cells is a pool of fetal stem cells, which could explain why keratin K19 staining of luminal cells in the fetal breast remains homogeneously positive (Anbazhagan et al. 1998). According to this hypothesis postnatal keratin K19-positive cells are descendants of a fetal pool of temporary stem cells, and further expansion of these relies largely on self-renewal within this compartment. Such a scenario would support the idea of a fetal origin of breast cancer and explain the K19positive-lineage-restricted phenotype of the majority of human breast cancers.

\section{ESTABLISHED CELL LINES}

The dramatic advances in long-term culture of normal human breast epithelial cells were followed by a desire to make established, nonmalignant cell lines for breast cancer research. The first spontaneously immortalized cell line pertinent to breast biology, COMMA-1D, was isolated from normal mid-pregnant BALB/c mice (Danielson et al. 1984). In contrast to mouse cells, nonmalignant human cells do not immortalize spontaneously (Harris 1987). Steady improvements in culture technology have allowed analysis of the changes associated with immortalization of human breast epithelial cells (Romanov et al. 2001). But the establishment of immortal human mammary epithelial cells requires the use of slightly abnormal tissue-for example, from in benign fibrocystic disease-as starting material. Petersen and colleagues were the first to establish a spontaneously immortal, nonmalignant human breast epithelial cell line, HMT-3522, from such tissue (Briand et al. 1987). The advantage of this particular cell line was that it gave rise to a continuum of autonomously growing and increasingly malignant and tumorigenic sublines. This provided the opportunity to study the molecular aspects of stepwise transformation leading to human breast cancer in the same genetic background (Briand et al. 1996). Another cell line from a similar source that had similar properties was the MCF-10A line established by Fred Miller and colleagues (Soule et al. 1990). They too established a cancer progression continuum from the cell line but with the use of c-Ha-ras (Heppner et al. 2000).

An unexpected characteristic of these and other subsequently spontaneously immortalized human breast epithelial cell lines, as well as their transformed derivatives, is the conspicuous lack of a complete keratin K19-positive lineage (Trask et al. 1990; Santner et al. 2001). Therefore, irrespective of the fact that these cell lines have many properties in common 
with the mouse equivalent, COMMA-1D, in terms of stem cell properties, they fail to show the same broadness of differentiation repertoire. One of the most frustrating consequences of this characteristic is that the cells cannot be used as models for estrogen-induced breast cancer. This is because the nonmalignant precursor cells lack estrogen receptor altogether, probably because they lack the keratin K19 lineage differentiation program. To overcome this challenge, investigators have transfected estrogen receptors into the cells, but the phenotype is the opposite of what was expected, because the proliferation of the cells is inhibited by estrogen (Zajchowski et al. 1993). Therefore, even after years of intense work with breast cell lines, we still do not have a reliable culture model for estrogenreceptor positive normal mammary epithelial cells despite the fact that estrogen-receptor positive tumors constitute the majority of breast carcinomas.

The discovery of keratin K19 as a hallmark of human breast cancer and the realization that long-term culture strategies apparently selected for keratin K19 negativity prompted further characterization of lineage progression in culture aimed at a better understanding of human breast epithelial stem and progenitor cells. The first clue to the true lineage identity of long-term cultured normal human breast epithelial cells came from comparative studies of the newly established normal and cancer cell lines. Surprisingly, genes highly expressed in normal cells, candidates for tumor suppressor genes, all turned out to be markers of myoepithelial/basal cells (Zou et al. 1994). The growth advantage these cells have in the serumfree medium used for these studies became even more clear with the availability of antibodies against smooth muscle actin (Petersen and van Deurs 1988). Specifically, Petersen and colleagues found that basal/myoepithelial cells, which are normally quiescent in vivo, can be induced to grow vigorously in serum-free culture and lose characteristics of myoepithelial differentiation, retaining only residual basallike properties after a few cell divisions. Others found that basal cells emerging from postcrisis culture of breast epithelium in serum-free medium gained a partial luminal phenotypeas revealed by the coexpression of the luminal keratins K8 and K18 and basal-like keratins K5 and K14 (Taylor-Papadimitriou et al. 1989). Thus, in general, long-term culture leads to selection for basal/myoepithelial cells, and a partial loss of the myoepithelial differentiation program along with a partial gain of a luminal differentiation program (albeit without keratin K19 expression). All human breast epithelial cell lines established thus far display this phenotype. Although in vivo equivalent of these cells has not been found, this particular culture profile is thought to reflect the existence of human breast epithelial stem cells in the basal compartment, and the challenge is to define them at the single-cell level (Taylor-Papadimitriou et al. 1989). If such thinking is correct, then either the majority of keratin K19 positive breast cancers originate from luminal precursor cells, i.e., the cell-of-origin dictates the differentiation repertoire (Wazer et al. 1995; Ince et al. 2007; Villadsen et al. 2007) or stem cells undergo pathological reprogramming by mutations and epigenetic changes to take on a luminal lineage program (Polyak 2007).

The lack of appropriate cell culture technology for spontaneous expansion of candidate breast cancer precursors that would maintain keratin K19 expression led to the development of modified culture protocols to circumvent this negative selection. The first established nonmalignant breast epithelial cell line with a profile similar to human breast cancer was generated by immortalization with SV-40 (Bartek et al. 1991). Apparently, human breast cells have different thresholds for immortalization, and this is undoubtedly lineage dependent (Romanov et al. 2001; Rangarajan et al. 2004). Thus, a more detailed analysis of the phenotypes emerging as a consequence of immortalization with variants of HPV E6/E7 revealed that both basal-like and luminal-like lineages could be immortalized, depending on the specific agent used (Wazer et al. 1995). So far attempts to generate established mammary epithelial cell lines with a full differentiation repertoire that includes expression of keratin K19 by using less potent oncogenes, such as hTERT, 
have failed. Therefore, despite the success different immortalization protocols had in making new cell lines, early attempts failed to provide an unequivocal link between putative basallike stem cells and keratin K19-positive human breast cancer precursor cells. We now know that, to establish this link, it is necessary to combine immortalization with different cell sorting protocols (Gudjonsson et al. 2002; Villadsen et al. 2007). The most promising new developments in cell culture technology have recently allowed long-term expansion of K19-positive cells from some primary tissues in the absence of immortalization (Garbe et al. 2009).

\section{THE IDENTITY OF BREAST EPITHELIAL STEM CELLS}

Because all attempts to match the phenotype of established basal-like human breast epithelial cell lines to that of the majority of human breast tumors failed, the widely held notion that breast cancer originates from cells within the luminal epithelial lineage remained largely unchallenged. For this reason, the characterization of cells within the luminal lineage became highly warranted. In addition its heterogeneity of expression of keratin K19, the luminal compartment was also found to be functionally heterogeneous. Specifically, Petersen and colleagues showed that clonal culture of luminal epithelial cells in the presence of cAMP-elevating cholera toxin resulted in the focal conversion of luminal epithelial cells into basal-like cells (Petersen and van Deurs 1988). This finding was confirmed and elaborated in a series of independent studies, and it was interpreted as evidence for stem cell activity (Kao et al. 1995; Huper and Marks 2007). That cells converted by cAMP treatment indeed represent cells of the basal lineage was shown by immunomagnetical sorting of the cells based on surface markers and proteomics studies (Péchoux et al. 1999). When the cells were plated on a reconstituted basement membrane, a minority of luminal cells formed branched end-bud-like structures (Sun et al. 1999) whereas the majority formed acinus-like spheres as previously observed (Petersen et al. 1992); this showed the cellular heterogeneity within the luminal epithelial compartment. Because the formation of these branched structures is dependent on the presence of basal cells, the observation supported the idea that multipotent stem cells are present within the luminal lineage (Sun et al. 1999). Intriguingly, purified basal cells on basement membrane (BM) exclusively form relatively large spherical structures with a central core of squamous metaplasia (Petersen et al. 1992; Sun et al. 1999). However, about $5 \%$ of these structures are formed by basal-like stem cells-as defined by their ability repopulate a cleared fat pad or a subrenal extracellular matrix implant (Eirew et al. 2008; Lim et al. 2009). Whether the stem cell activity obtained from these purifications pertains to Bartek's keratin K19-positive or -negative luminal epithelial cells remains to be seen. However, the fact that these $5 \%$ of basal stem-cell-like cells are apparently not cellular precursors even of basal-like breast cancer suggests that they belong to the collaterally expanded keratin K19-negative population referred to earlier on (Lim et al. 2009).

The first evidence for a third type of human breast epithelial cell other than luminal and myoepithelial cells was obtained in studies using single-cell FACS (Stingl et al. 2001). Breast tissue was disaggregated in a low concentration of collagenase and cultured for one day to a week. Single cells were obtained by treatment with trypsin and dispase., and colony-forming assays were performed mostly in low-density culture $\left(100\right.$ cells $\left./ \mathrm{cm}^{2}\right)$ on dishes with a preestablished feeder layer of irradiated NIH-3T3 cells. Multipotent cells were identified based on the formation of two-cell-type islets with a central zone of luminal epithelial cells and peripheral zone of myoepithelial cells (Petersen and van Deurs 1987; Stingl et al. 2001). In lowdensity cultures, the central zone expressed keratin K19 (Stingl et al. 2001). In single-cell culture after FACS, the central zone was characterized by the expression of sialomucin (Stingl et al. 2001). The most intriguing observation was that the central zone failed to express keratin K14. Thus, whereas occasional basal breast epithelial cells in culture express luminal markers such as sialomucin and K18, this is generally 
considered pseudoluminal differentiation, as revealed by expression of the remaining myoepithelial markers, such as keratin K5, K14, and K17 (Rønnov-Jessen et al. 1996; Stingl et al. 2001). The bona fide presence of islets composed of K14-negative, sialomucin-positive cells and K14-positive sialomucin-negative cells from a single cell strongly favors a stem cell origin. Nevertheless, the precise identity of human breast epithelial stem cells was not revealed on this occasion. However, bi-potent colonyforming cells were enriched in the EGF-receptor-positive or sialomucin-negative fraction, indicating a basal or nonluminal origin.

Based on this approach Petersen and colleagues hypothesized that multipotent, keratin K19-positive breast cancer precursor cells could be isolated prospectively and immortalized based on sialomucin- and EpCam/epithelialspecific antigen (ESA) sorting. The cells could then be examined by single-cell cloning, morphogenesis in a reconstituted basement membrane $(\mathrm{rBM})$, and xenotransplantation assays in mice (Gudjonsson et al. 2002). They succeeded in immortalizing sialomucin-negative/ ESA- positive cell lines that gave rise to lineage-restricted sialomucin-positive luminal epithelial cells and Thy-1-positive myoepithelial cells. Most intriguingly, the sialomucin-negative ESA-positive cell lines were keratin K19positive and formed elaborate, branching terminal-duct-like structures in the rBM assay (Gudjonsson et al. 2002). On sectioning and staining, these structures were found to be composed of an inner layer of luminal-like epithelial cells surrounded by a basal layer of myoepithelial-like cells (Gudjonsson et al. 2002). Thus, this represented the first example of a multipotent breast cell line with the propensity to express keratin K19, linking stem/progenitor cells with breast cancer.

\section{MAMMOSPHERE CULTURES}

Clonal growth in nonadherent culture was originally used to test for self-renewal capacity in cultures of neural cells (Reynolds and Weiss 1996). Suspension culture led to formation of so-called neurospheres, which consisted of $4 \%-20 \%$ stem cells. This technology was adopted for human breast epithelial cells by Gabriella Dontu and Max Wicha in 2002 (Dontu et al. 2003). Mammospheres formed from primary cells seeded at a density of 20,000 cells per well in lowadherent multiwell dishes. These mammospheres could be serially passaged with a colonyforming frequency of about $4 / 1000$ cells for up to five consecutive passages and their gene expression profile was consistent with their presumed progenitor properties (Dontu et al. 2003). Moreover, clonal monolayer culture under differentiating conditions led to the formation of mixed colonies of luminal-like and myoepithelial-like cells-an indication of multipotency. Remarkably, under differentiating conditions inside an rBM myoepithelial cells stained for CALLA and luminal epithelial cells, in the presence of prolactin, stained for $\beta$-casein. This was the first documentation of tissue-specific differentiation of human breast epithelial cells ex vivo. Similar data have recently been obtained in studies using mammary repopulating cells; approximately $5 \%$ of the colonies inside the rBM stained with an antibody against milk proteins (Lim et al. 2009).

The validity of the mammosphere assay was further substantiated by the finding that mammospheres were enriched for aldehyde dehydrogenase (ALDH1), another marker of stem cells (Ginestier et al. 2007). Imunohistochemical staining of normal breast tissue with an antibody against ALDH1 identified positive cells both in the luminal and basal compartments (Ginestier et al. 2007). The obvious advantage of ALDH1 as an additional marker of breast stem/progenitor cells is that the same marker is widely applicable for breast cancer cells with stem-cell-like features (Huang et al. 2009). These cells are also characterized by low levels of heat stable antigen (CD24) and high levels of hyaluronan receptor (CD44) expression (Al-Hajj et al. 2003; Shipitsin et al. 2007). Further support for the idea that mammosphere and ALDH1 assays are relatively fast and reliable means to predict the presence of breast stem/ progenitor cells comes from in vivo studies of cells transplanted into NOD/SCID mice humanized with stromal fibroblasts in the cleared 
fat pad (Kuperwasser et al. 2004; Ginestier et al. 2007). Originally, appropriate morphogenesis occurred following transplantation of entire organoids, which maintained their structure and function (Kuperwasser et al. 2004). Remarkably, this was further refined to an engraftment-like assay in which cells in suspension can also undergo such morphogenesis. This allowed researchers to perform dilution experiments as well as cell sorting before engraftment (Ginestier et al. 2007). Relevant morphogenesis has now been obtained in the absence of human stroma following transplantation under the kidney capsule of NOD/SCID mice or in the cleared fat pads of NOG mice (Eirew et al. 2008; Lim et al. 2009). However, the identity of the repopulating mammary epithelial cells in terms of ALDEFLUOR readout remains somewhat unclear (Ginestier et al. 2007; Lim et al. 2009).

\section{PROFILING HUMAN BREAST EPITHELIAL STEM CELLS}

Three different approaches have been applied to obtain molecular profiles of human breast epithelial stem/progenitor cells. One compared mammospheres with cells cultured under differentiating conditions and then analyzed by microarray experiments (Dontu et al. 2003). The other compared uncultured lin -/CD24-/ CD44+ candidate stem/progenitor cells with presumably differentiated luminal CD24+ cells by SAGE (Serial Analysis of Gene Expression) (Shipitsin et al. 2007). The third study used a combination of these two approaches (Raouf et al. 2008). A comparison of the data obtained in these studies indicates that basically the same cell population is being investigated. Some of the markers that show high levels of expression in progenitor-enriched fraction in at least two of the studies include FGFR, insulin-like growth factor binding protein-7, Notch3, decorin, Thy1, growth arrest specific-6, and tenascin C. Given these markers, it is very likely that the bipotent human mammary epithelial stem cell is more similar to myoepithelial cells than to luminal epithelial cells, as is the case with stem cells of the mouse mammary gland
(Fig. 3). Although these studies all point to significant differences between breast stem/progenitor cells and lineage-restricted luminal epithelial cells_-particularly in NOTCH signaling-little is known about the mechanism governing differentiation toward the mature myoepithelial lineage. This may be because no good culture conditions exist for the maintenance of terminally differentiated myoepithelial cells: In short-term cultures, myoepithelial cells may enter differentiation programs, including metaplastic conversion into a squamous-like phenotype (Petersen and van Deurs 1988).

An important consequence of having a single protocol for sorting normal- and cancerderived stem cells is the potential to make very accurate comparisons with little or no noise from irrelevant cells. Only one study so far has tried this (Shipitsin et al. 2007). Intriguingly, it was found that cancer and normal CD44-positive cells differed with respect to pathways involving TGF- $\beta 1$, dynamin, fibronectin, caveolin, and casein kinase II, which were all up-regulated in CD44-positive cancer cells (Shipitsin et al. 2007). Indeed the activation of TGF- $\beta$ signaling in cancer-derived CD44-positive cells was interrogated with a specific kinase inhibitor (LY2109761), which surprisingly showed that relief from TGF- $\beta$ signaling rapidly led to conversion of mesenchymal-like cells to a more epithelial-like morphology (Shipitsin et al. 2007). It is possible that the myoepithelial lineage that displays features consistent with an EMT (epithelial to mesenchymal transition) is maintained primarily as a consequence of a continuous TGF- $\beta$ signaling, which is known to induce EMT in breast epithelial cells (Valcourt et al. 2005). But more importantly, it follows that genetic or epigenetic aberrations that affect TGF- $\beta$ signaling will switch cells toward a more luminal epithelial lineage. If this hypothesis is correct, it would offer a plausible explanation for the enigmatic skewing of most breast cancer clones toward the luminal epithelial lineage.

One of the most frequent loss-of-function in human breast cancer affects the tumor suppressor PTEN. PTEN acts as a lipid phosphatase that dephophorylates phosphatidylinositol 
Mammary Epithelial Cell Hierarchy
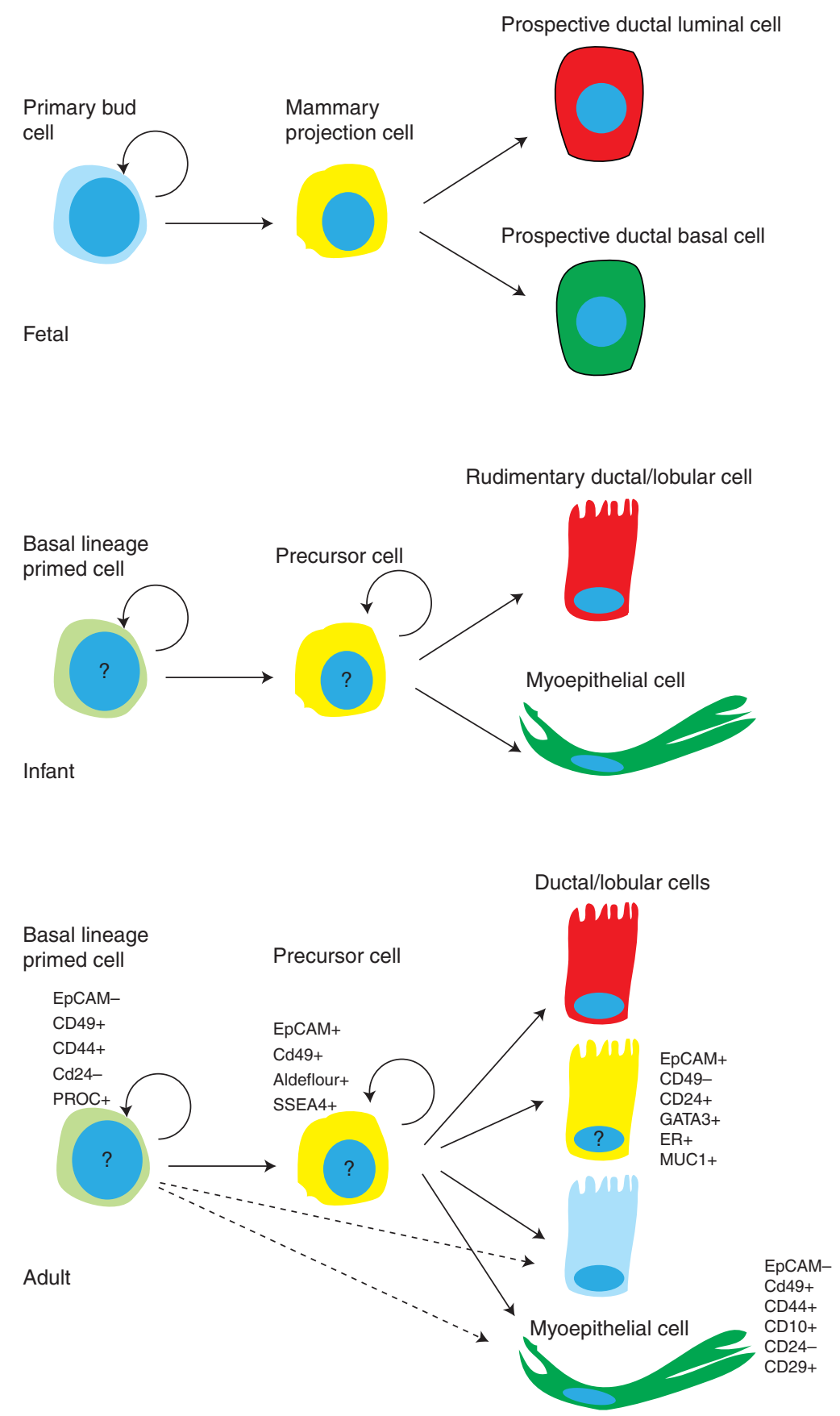

Figure 3. Schematic model of the human breast lineage hierarchy at different developmental stages. The most primitive fetal cells are double-negative for keratin K14 and K19 represented with a blue cytoplasm. Stem cells in the infant and adult human breast are thought to be lineage primed along the basal lineage represented by a light green cytoplasm. Multipotent progenitor cells are double-positive for keratin K14 and K19 represented by a yellow cytoplasm. Differentiated breast basal/myoepithelial and epithelial cells are either positive for keratin K14 (green), keratin K19 (red), double positive (yellow), or double negative (blue). Additional markers are listed for the different classes of cells in the adult breast. 
(3,4,5)-trisphosphate (PIP3); this antagonizes the growth-promoting PI3-K/Akt pathway and loss of PTEN correlates with poor prognosis in breast cancer (Korkaya et al. 2009). TGF- $\beta$ induces microRNAs of the miRNA-200 family, which target PTEN expression and therefore lead to the activation of the Akt kinase pathway (Kato et al. 2009). It follows that, under normal conditions, inhibition of TGF- $\beta$ should lead to a decline in stem cell activity, which is in accordance with a shift toward the luminal epithelial lineage. A similar interruption of TGF- $\beta$ signaling in cancer may have the same effect. The fact that mammary epithelial stem cells seem to co-sort with cells of the myoepithelial lineage strongly supports the concept of so-called lineage-priming within the stem cell compartment (Delorme et al. 2009). According to this, stem cells are not a "blank slate" in terms of expression of differentiationassociated genes but rather express subsets of genes associated with the differentiation pathways to which they commit. Clonal expansion of stem cells and progenitors along with carcinogenesis may eventually lead to reprogramming and evolution of malignant clones, which form tumors devoid of the original benign stem-celllike clone. This could explain the massive skew toward luminal differentiation in human breast cancer.

\section{A BREAST STEM CELL HIERARCHY PREDICTING CELL-OF-ORIGIN IN BREAST CANCER}

A consequence of this scenario would be that, in the multistep evolution of a cancer, mutations in stem cells or their lineage-restricted progeny lead to expansion of new clones that initially contribute to tumor heterogeneity (because they remain true to their lineage affiliation at the time of mutation). Eventually, however, there is an apparent lineage restriction because of a growth advantage in the metastatic clone. This prediction was recently born out in several independent studies. Polyak and colleagues found that metastatic lesions are more lineage restricted as revealed by staining for CD44 and CD24. Surprisingly, in paired samples of primary and metastatic lesions, the latter were found to be more frequently and uniformly CD24 positive (Shipitsin et al. 2007). Petersen and colleagues found evidence for the existence a breast stem cell hierarchy by sorting breast epithelial cells into stem-cell-like cells, luminal epithelial cells, and myoepithelial cells, submitting all of them to the same immortalization protocol (HPV E6/E7) (Villadsen et al. 2007). Intriguingly, the lineage-restricted progeny of the stem cells essentially remained true to their differentiation program despite immortalization for many generations. Three different progenies were found, showing differentiation programs reminiscent of similar cell types in situ. A scrutiny of 50 human breast carcinomas revealed that they could be subdivided based on staining with keratin K14 and K19 into the same categories as those found in the normal human breast (Fig. 4). In another study, basal-like and luminal-like breast epithelial cells were selectively expanded under different culture conditions and transformed with an identical combination of oncogenes: hTERT, SV-40 LT7st, and H-ras-v12 (Ince et al. 2007). Depending exclusively on the cell of origin, the derived tumors showed completely different histological appearances and differentiation programs. Remarkably, the lineage programs were essentially maintained during tumor development.

\section{CONCLUDING REMARKS}

Returning to our introductory remarks concerning the possibility that different stem cells exist at different stages of development, we can now say that, whereas human breast epithelial stem cells may exist within the basal layer, the luminal compartment or its reprogrammed equivalent can provide precursor cells for breast cancer. The breast is not the only organ in which we notice this. Recently, in the prostate it was shown that, even though basal cells are widely accepted as the stem cells in organogenesis, luminal cells might serve as "facultative" stem or progenitor cells during prostate regeneration (Wang et al. 2009). Thus luminal progenitors are indeed multipotent and remain precursor cells for prostate cancer. This may also pertain 
A

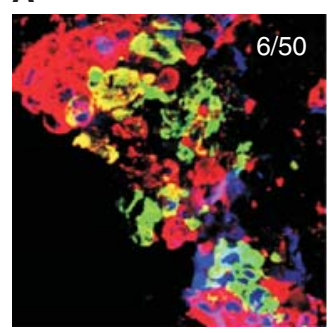

\section{B}

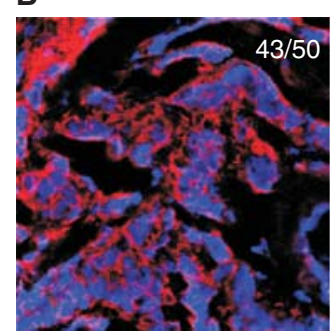

K19/K14/Nuclei

C

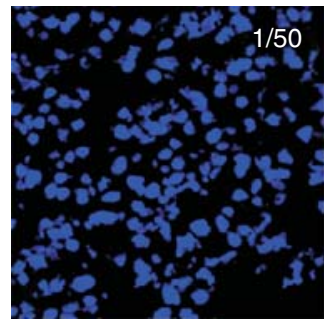

D

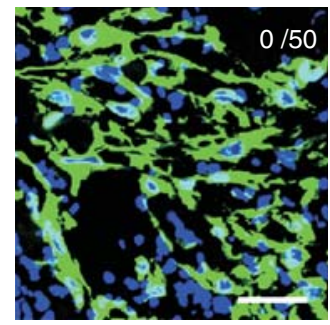

Figure 4. Keratin K19/K14 breast cancer subtypes. Multicolor imaging of cryostat sections of human breast carcinomas representing different subtypes as defined by combinations of staining with keratin K19 and K14. In a sample of 50 randomly selected primary breast carcinomas, 6 were double-positive for keratin K19 and K14 (A), 43 were positive for keratin K19 only $(B), 1$ was double-negative $(C)$, and none of them were positive for keratin K14 alone ( $D$; staining of a malignant myoepithelioma from a different sample) (Scale bar $=50 \mu \mathrm{m})$.

to the breast, because even basal-like breast cancer appears to originate from luminal-like progenitors. Thus, as in skin, lung, pancreas, and testis, in the human breast it may be relevant to distinguish between fetal development, puberty, monthly tissue homeostasis, and pregnancy when it comes to defining both the stem cell compartment and breast cancer precursor cells.

\section{ACKNOWLEDGMENTS}

The authors thank members of their laboratories for their critical reading of the manuscript and constructive discussions. Work in the authors' laboratories is supported by the National Cancer Institute (CA89393, CA116235, CA143233, and CA080111), Department of Defense (W81XWH-07-1-0294 and W81XWH-09-1-0131), Avon Foundation, Susan G. Komen Breast Cancer Research Foundation, Breast Cancer Research Foundation, and Novartis Oncology grants awarded to KP, and The Danish Cancer Society; Dansk Kræftforskningsfond; The EuroCSC contract no: 037632; The Lundbeck Foundation; The Novo Nordic Foundation; The Danish Research Agency, contract no. 2107-05-0006; DAN-ED; $\mathrm{NIH}$, contract no. R01CA064786; The Friis Foundation and The Simon Spies Foundation awarded to OWP. The use of human material has been reviewed by the Regional Scientific
Ethical Committees for Copenhagen and Frederiksberg and approved with reference to (KF) (11) 263995. Marianne T. Lund is acknowledged for expert technical assistance.

\section{REFERENCES}

Al-Hajj M, Wicha MS, Benito-Hernandez A, Morrison SJ, Clarke MF. 2003. Prospective identification of tumorigenic breast cancer cells. Proc Natl Acad Sci 100: 39833988.

Anbazhagan R, Osin PP, Bartkova J, Nathan B, Lane EB, Gusterson BA. 1998. The development of epithelial phenotypes in the human fetal and infant breast. J Pathol 184: 197-206.

Bartek J, Bartkova J, Kyprianou N, Lalani E-N, Staskova Z, Shearer M, Chang S, Taylor-Papadimitriou J. 1991. Efficient immortalization of luminal epithelial cells from human mammary gland by introduction of simian virus 40 large tumor antigen with recombinant retrovirus. Proc Natl Acad Sci 88: 3520-3524.

Bartek J, Taylor-Papadimitriou J, Miller N, Millis R. 1985. Patterns of expression of keratin 19 as detected with monoclonal antibodies in human breast tissues and tumours. Int J Cancer 36: 299-306.

Bissell MJ, Inman J. 2008. Reprogramming stem cells is a microenvironmental task. Proc Natl Acad Sci 105: 15637-15638.

Bocker W, Moll R, Poremba C, Holland R, Van Diest PJ, Dervan $P$, Burger H, Wai D, Ina Diallo R, Brandt B, et al. 2002. Common adult stem cells in the human breast give rise to glandular and myoepithelial cell lineages: A new cell biological concept. Lab Invest 82: 737-746.

Briand P, Petersen OW, van Deurs B. 1987. A new diploid nontumorigenic human breast epithelial cell line isolated and propagated in chemically defined medium. In Vitro Cell Dev Biol 23: 181-188. 
O.W. Petersen and K. Polyak

Briand P, Nielsen KV, Madsen MW, Petersen OW. 1996. Trisomy $7 \mathrm{p}$ and malignant transformation of human breast epithelial cells following epidermal growth factor withdrawel. Cancer Res 56: 2039-2044.

Dairkee SH, Blayney C, Smith HS, Hackett AJ. 1985. Monoclonal antibody that defines human myoepithelium. Proc Natl Acad Sci82: 7409-7413.

Danielson KG, Oborn CJ, Durban EM, Butel JS, Medina D. 1984. Epithelial mouse mammary cell line exhibiting normal morphogenesis in vivo and functional differentiation in vitro. Proc Natl Acad Sci 81: 3756-3760.

Delorme B, Ringe J, Pontikoglou C, Gaillard J, Langonne A, Sensebe L, Noel D, Jorgensen C, Haupl T, Charbord P. 2009. Specific lineage-priming of bone marrow mesenchymal stem cells provides the molecular framework for their plasticity. Stem Cells 27: 1142-1151.

Dontu G, Wicha MS. 2005. Survival of mammary stem cells in suspension culture: Implications for stem cell biology and neoplasia. J Mammary Gland Biol Neoplasia 10: 75-86.

Dontu G, Abdallah WM, Foley JM, Jackson KW, Clarke MF, Kawamura MJ, Wicha MS. 2003. In vitro propagation and transcriptional profiling of human mammary stem/progenitor cells. Genes Dev 17: 1253-1270.

Eirew P, Stingl J, Raouf A, Turashvili G, Aparicio S, Emerman JT, Eaves CJ. 2008. A method for quantifying normal human mammary epithelial stem cells with in vivo regenerative ability. Nat Med 14: 1384-1389.

Garbe JC, Bhattacharya S, Merchant B, Bassett E, Swisshelm K, Feiler HS, Wyrobek AJ, Stampfer MR. 2009. Molecular distinctions between stasis and telomere attrition senescence barriers shown by long-term culture of normal human mammary epithelial cells. Cancer Res 69: 7557-7568.

Ginestier C, Hur MH, Charafe-Jauffret E, Monville F, Dutcher J, Brown M, Jacquemier J, Viens P, Kleer CG, Liu S, et al. 2007. ALDH1 is a marker of normal and malignant human mammary stem cells and a predictor of poor clinical outcome. Cell Stem Cell 1: 555-567.

Gudjonsson T, Villadsen R, Nielsen HL, Ronnov-Jessen L, Bissell MJ, Petersen OW. 2002. Isolation, immortalization, and characterization of a human breast epithelial cell line with stem cell properties. Genes Develop 16: 693-706.

Hammond SL, Ham RG, Stampfer MR. 1984. Serum-free growth of human mammary epithelial cells: Rapid clonal growth in defined medium and extended serial passage with pituitary extract. Proc Natl Acad Sci 81: 5435-5439.

Harris CC. 1987. Human tissues and cells in carcinogenesis research. Cancer Res 47: 1-10

Heppner GH, Miller FR, Shekhar PM. 2000. Nontransgenic models of breast cancer. Breast Cancer Res 2: 331-334.

Hilakivi-Clarke L, de Assis S. 2006. Fetal origins of breast cancer. Trends Endocrinol Metab 17: 340-348.

Howard BA, Gusterson BA. 2000. Human breast development. J of Mammary Gland Biol and Neoplasia 5: 119-137.

Huper G, Marks JR. 2007. Isogenic normal basal and luminal mammary epithelial isolated by a novel method show a differential response to ionizing radiation. Cancer Res 67: $2990-3001$.
Ince TA, Richardson AL, Bell GW, Saitoh M, Godar S, Karnoub AE, Iglehart JD, Weinberg RA. 2007. Transformation of different human breast epithelial cell types leads to distinct tumor phenotypes. Cancer Cell 12: 160-170.

Jolicoeur F. 2005. Intrauterine breast development and the mammary myoepithelial lineage. J Mammary Gland Biol and Neoplasia 10: 199-210.

Kao C-Y, Nomata K, Oakley CS, Welsch CW, Chang C-C. 1995. Two types of normal human breast epithelial cells derived from reduction mammoplasty: Phenotypic characterization and response to SV40 transfection. Carcinogenesis 16: 531-538.

Kato M, Putta S, Wang M, Yuan H, Lanting L, Nair I, Gunn A, Nakagawa Y, Shimano H, Todorov I, Rossi JJ, Natarajan R. 2009. TGF-beta activates Akt kinase through a microRNA-dependent amplifying circuit targeting PTEN. Nat Cell Biol 11: 881-889.

Korkaya H, Paulson A, Charafe-Jauffret E, Ginestier C, Brown M, Dutcher J, Clouthier SG, Wicha MS. 2009. Regulation of mammary stem/progenitor cells by PTEN/Akt/beta-catenin signaling. PLoS Biol 7: e1000121.

Kuperwasser C, Chavarria T, Wu M, Magrane G, Gray JW, Carey L, Richardson A, Weinberg RA. 2004. Reconstruction of functionally normal and malignant human breast tissues in mice. Proc Natl Acad Sci U S A 101: 4966-4971.

Lim E, Vaillant F, Wu D, Forrest NC, Pal B, Hart AH, AsselinLabat ML, Gyorki DE, Ward T, Partanen A, et al. 2009. Aberrant luminal progenitors as the candidate target population for basal tumor development in BRCA1 mutation carriers. Nat Med 15: 907-913.

Nagle RB, Böcker W, Davis JR, Heid HW, Kaufman M, Lucas DO, Jarasch E-D. 1986. Characterization of breast carcinomas by two monoclonal antibodies distinguishing myoepithelial from luminal epithelial cells. J Histochem Cytochem 34: 869-881.

Pece S, Tosoni D, Confalonieri S, Mazzarol G, Vecchi M, Ronzoni S, Bernard L, Viale G, Pelicci PG, Di Fiore PP. 2010. Biological and molecular heterogeneity of breast cancers correlates with their cancer stem cell content. Cell 140: 62-73.

Péchoux C, Gudjonsson T, Rønnov-Jessen L, Bissell MJ, Petersen OW. 1999. Human mammary luminal epithelial cells contain progenitors to myoepithelial cells. Dev Biol 206: 88-99.

Petersen OW, van Deurs B. 1987. Preservation of defined phenotypic traits in short-time cultured human breast carcinoma derived epithelial cells. Cancer Res 47: 856-866.

Petersen OW, van Deurs B. 1988. Growth factor control of myoepithelial-cell differentiation in cultures of human mammary gland. Differentiation 39: 197-215.

Petersen OW, Rønnov-Jessen L, Howlett AR, Bissell MJ. 1992. Interaction with basement membrane serves to rapidly distinguish growth and differentiation pattern of normal and malignant human breast epithelial cells. Proc Natl Acad Sci 89: 9064-9068.

Polyak K. 2007. Breast cancer: origins and evolution. J Clin Invest 117: 3155-3163.

Rangarajan A, Hong SJ, Gifford A, Weinberg RA. 2004. Species- and cell type-specific requirements for cellular transformation. Cancer Cell 6: 171-183. 
Raouf A, Zhao Y, To K, Stingl J, Delaney A, Barbara M, Iscove N, Jones S, McKinney S, Emerman J, Aparicio S, Marra M, Eaves C. 2008. Transcriptome analysis of the normal human mammary cell commitment and differentiation process. Cell Stem Cell 3: 109-118.

Reynolds BA, Weiss S. 1996. Clonal and population analyses demonstrate that an EGF-responsive mammalian embryonic CNS precursor is a stem cell. Dev Biol 175: 1-13.

Romanov SR, Kozakiewics BK, Holst CR, Stampfer MR, Haupt LM, Tlsty TD. 2001. Normal human mammary epithelial cells spontaneously escape senescence and acquire genomic changes. Nature 409: 633-637.

Rønnov-Jessen L, Petersen OW, Bissell MJ. 1996. Cellular changes involved in conversion of normal to malignant breast: The importance of the stromal reaction. Physiol Rev 76: 69-125.

Rudland PS, Hallowes RC, Cox SA, Ormerod EJ, Warburton MJ. 1985. Loss of production of myoepithelial cells and basement membrane proteins but retention of response to certain growth factors and hormones by a new malignant human breast cancer cell strain. Cancer Res 45: 3864-3877.

Russo J, Russo IH. 2004. Development of the human breast. Maturitas 49: 2-15.

Santner SJ, Dawson PJ, Tait L, Soule HD, Eliason J, Mohamed AN, Wolman SR, Heppner GH, Miller FR. 2001. Malignant MCF10CA1 cell lines derived from premalignant human breast epithelial MCF10AT cells. Breast Cancer Res Treat 65: 101-110.

Shipitsin M, Campbell LL, Argani P, Weremowicz S, Bloushtain-Qimron N, Yao J, Nikolskaya T, Serebryiskaya T, Beroukhim R, Hu M, et al. 2007. Molecular definition of breast tumor heterogeneity. Cancer Cell 11: 259-273.

Sørlie T, Perou CM, Tibshirani R, Aas T, Geisler S, Johnsen $\mathrm{H}$, Hastie T, Eisen MB, van de Rijn M, Jeffrey SS, Thorsen T, Quist H, Matese JC, Brown PO, Botstein D, Eystein Lonning P, Borresen-Dale AL. 2001. Gene expression patterns of breast carcinomas distinguish tumor subclasses with clinical implications. Proc Natl Acad Sci 98: 10869-10874.

Soule HD, McGrath CM. 1986. A simplified method for passage and long-term growth of human mammary epithelial cells. In Vitro Cell Dev Biol 22: 6-12.

Soule HD, Maloney TM, Wolman SR, Peterson WD, Brenz R, McGrath CM, Russo J, Pauley RJ, Jones RF, Brooks SC. 1990. Isolation and characterization of a spontaneously immortalized human breast epithelial cell line, MCF-10. Cancer Res 50: 6075-6086.
Stampfer M, Hallowes RC, Hackett AJ. 1980. Growth for normal human mammary cells in culture. In Vitro 16: $415-425$.

Stingl J, Eaves CJ, Zandieh I, Emerman JT. 2001. Characterization of bipotent mammary epithelial progenitor cells in normal adult human breast tissue. Breast Cancer Res Treat 67: 93-109.

Sun W, Kang K-S, Morita I, Trosko JE, Chang C-C. 1999. High susceptibility of a human breast epithelial cell type with stem cell characteristics to telomerase activation and immortalization. Cancer Res 59: 6118-6123.

Taylor-Papadimitriou J, Stampfer M, Bartek J, Lewis A, Boshell M, Lane EB, Leigh IM. 1989. Keratin expression in human mammary epithelial cells cultured from normal and malignant tissue: Relation to in vivo phenotypes ad influence of medium. J Cell Sci 94: 403-413.

Trask DK, Band V, Zajchowski DA, Yaswen P, Suh T, Sager R. 1990. Keratins as markers that distinguish normal and tumor-derived mammary epithelial cells. Proc Natl Acad Sci 87: 2319-2323.

Valcourt U, Kowanetz M, Niimi H, Heldin CH, Moustakas A. 2005. TGF-beta and the Smad signaling pathway support transcriptomic reprogramming during epithelialmesenchymal cell transition. Mol Biol Cell 16: 19872002.

Villadsen R, Fridriksdottir AJ, Rønnov-Jessen L, Gudjonsson T, Rank F, Labarge MA, Bissell MJ, Petersen OW. 2007. Evidence for a stem cell hiearachy in the adult human breast. J Cell Biol 177: 87-101.

Wang X, Kruithof-de Julio M, Economides KD, Walker D, Yu H, Halili MV, Hu YP, Price SM, Abate-Shen C, Shen MM. 2009. A luminal epithelial stem cell that is a cell of origin for prostate cancer. Nature 461: 495-500.

Wazer DE, Liu X-L, Chu C, Gao Q, Band V. 1995. Immortalization of distinct human mammary epithelial cell types by human papilloma virus 16 E6 or E7. Proc Natl Acad Sci 92: 3687-3691.

Zajchowski DA, Sager R, Webster L. 1993. Estrogen inhibits the growth of estrogen receptor-negative, but not estrogen receptor-positive, human mammary epithelial cells expressing a recombinant estrogen receptor. Cancer Res 53: 5004-5011.

Zou Z, Anisowicz A, Hendrix MJC, Thor A, Neveu M, Sheng S, Rafidi K, Seftor E, Sager R. 1994. Maspin, a serpin with tumor-suppressing activity in human mammary epithelial cells. Science 263: 526-529. 


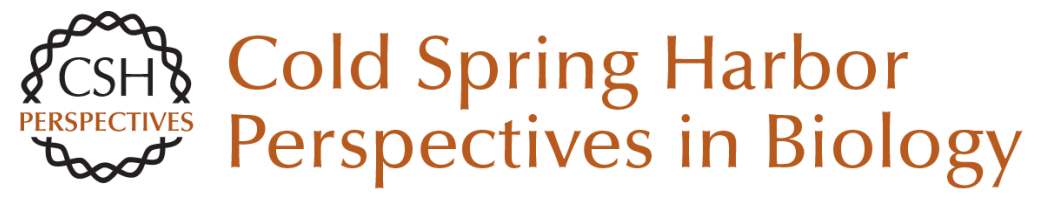

\section{Stem Cells in the Human Breast}

Ole William Petersen and Kornelia Polyak

Cold Spring Harb Perspect Biol 2010; doi: 10.1101/cshperspect.a003160

Subject Collection The Mammary Gland as an Experimental Model

On the Role of the Microenvironment in Mammary Gland Development and Cancer Derek Radisky

On Using Functional Genetics to Understand Breast Cancer Biology

Kornelia Polyak

On Oncogenes and Tumor Suppressor Genes in the Mammary Gland

Rushika M. Perera and Nabeel Bardeesy

On Leukocytes in Mammary Development and

Cancer

Cyrus M. Ghajar

On Chromatin Remodeling in Mammary Gland

Differentiation and Breast Tumorigenesis Kornelia Polyak

On Hormone Action in the Mammary Gland J.M. Rosen

TGF- $\beta$ Biology in Mammary Development and Breast Cancer

Harold Moses and Mary Helen Barcellos-Hoff

A Compendium of the Mouse Mammary Tumor Biologist: From the Initial Observations in the House Mouse to the Development of Genetically Engineered Mice

Robert D. Cardiff and Nicholas Kenney
On How Mammary Gland Reprogramming

Metalloproteinases Couple Form with Function Bonnie F. Sloane

On Molecular Mechanisms Guiding Embryonic

Mammary Gland Development Gertraud W. Robinson

On Stem Cells in the Human Breast Mark A. LaBarge

On Murine Mammary Epithelial Stem Cells:

Discovery, Function, and Current Status Jeffrey M. Rosen

On In Vivo Imaging in Cancer David Piwnica-Worms

Choosing a Mouse Model: Experimental Biology in Context--The Utility and Limitations of Mouse Models of Breast Cancer Alexander D. Borowsky

Mammary Gland ECM Remodeling, Stiffness, and Mechanosignaling in Normal Development and Tumor Progression Pepper Schedin and Patricia J. Keely

Molecular Mechanisms Guiding Embryonic

Mammary Gland Development Pamela Cowin and John Wysolmerski

For additional articles in this collection, see http://cshperspectives.cshlp.org/cgi/collection/

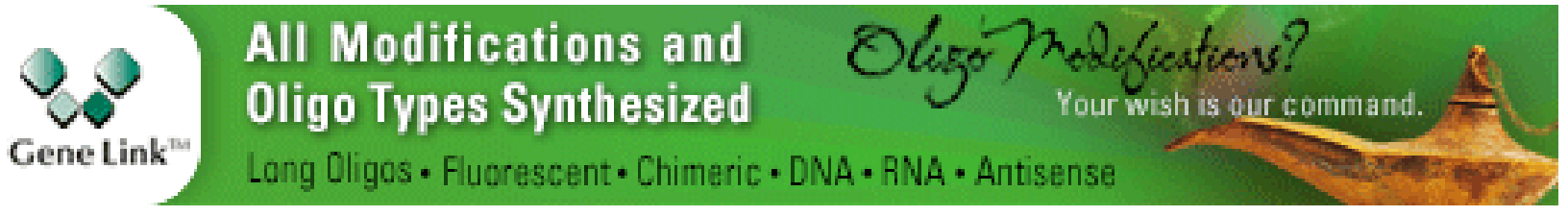


For additional articles in this collection, see http://cshperspectives.cshlp.org/cgi/collection/

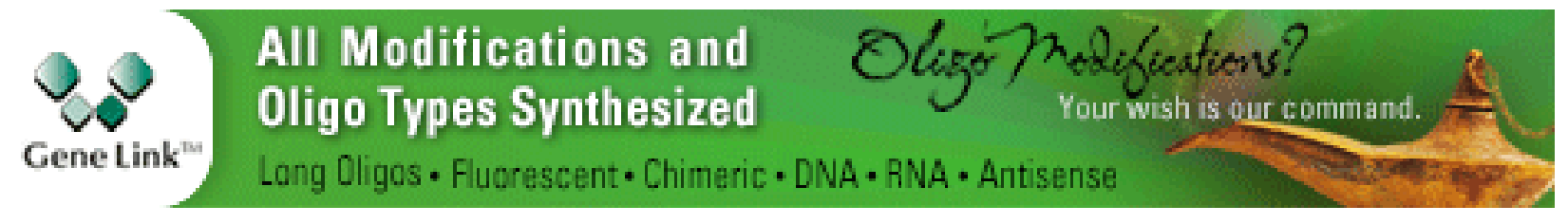

Copyright @ 2010 Cold Spring Harbor Laboratory Press; all rights reserved 